\title{
Hopelessness: Independent associations with health-related quality of life and short-term mortality after critical illness: A prospective, multicentre trial
}

Lotti Orwelius, Margareta Kristenson, Mats Fredrikson, Sten Walther and Folke Sjöberg

The self-archived postprint version of this journal article is available at Linköping University Institutional Repository (DiVA):

http:/ / urn.kb.se/ resolve?urn=urn:nbn:se:liu:diva- 143372

N.B.: When citing this work, cite the original publication.

Orwelius, L., Kristenson, M., Fredrikson, M., Walther, S., Sjöberg, F., (2017), Hopelessness:

Independent associations with health-related quality of life and short-term mortality after critical illness: A prospective, multicentre trial, J ournal of critical care, 41, 58-63.

https:// doi.org/ 10.1016/j.jcrc.2017.04.044

Original publication available at:

https:// doi.org/ 10.1016/j.jcrc.2017.04.044

Copyright: WB Saunders

http:// www.elsevier.com/ 


\section{Hopelessness: independent associations with health-related quality of life and short-term mortality after critical illness: a prospective, multicentre trial}

Lotti Orwelius PhD a,b lotti.orvelius@regionostergotland.se, Margareta Kristenson Professor, M.D. ${ }^{\mathrm{c}}$ margareta.kristenson@liu.se, Mats Fredrikson PhD ${ }^{\mathrm{b}}$ mats.fredrikson@liu.se, Sten Walther PhDc sten.walther@ regionostergotland.se, Folke Sjöberg Professor, M.D. ${ }^{\mathrm{a}, \mathrm{b}, \mathrm{d}}$ folke.sjoberg@liu.se

${ }^{\mathrm{a}}$ Departments of Intensive Care, ${ }^{\mathrm{b}}$ Clinical and Experimental Medicine, ${ }^{\mathrm{c}}$ Medicine and Health Sciences, ${ }^{\mathrm{d} B u r n s, ~ H a n d ~ a n d ~ P l a s t i c ~ S u r g e r y, ~ F a c u l t y ~ o f ~ H e a l t h ~ S c i e n c e s, ~ a l l ~ a t ~ t h e ~ L i n k o ̈ p i n g ~}$ University, County Council of Östergötland, Sweden.

Corresponding author:

Lotti Orwelius, Department of Intensive Care, University Hospital, SE-581 85 Linköping, Sweden.

Conflicts of interest: none

Financial disclosure: none

\section{Abbreviations}

APACHE II: Acute Physiology and Chronic health Evaluation II, CATS: Cognitive Activation Theory of Stress, COPD: Chronic Obstructive Pulmonary Disease, HRQoL: Health-Related Quality of Life, ICU: Intensive Care Unit, SF-36: Medical Outcome ShortForm. 


\section{Abstract}

Purpose: To assess the independent associations between ability to cope and hopelessness with measures of health-related quality of life (HRQoL) and their effects on mortality up to 3 years after discharge in patients who have been treated in an intensive care unit (ICU). Methods: A prospective, cross-sectional multicenter study of 980 patients. Ability to cope, hopelessness, and HRQoL were evaluated using validated scales. Questionnaires were sent to patients 6, 12, 24, and 36 months after discharge from ICU.

Results: After adjustment, low scores for ability to cope and high scores for hopelessness were both related to poorer HRQoL for all subscales (except for coping with bodily pain). Effects were in the same range as coexisting disease for physical subscales, and stronger for social and mental subscales. High scores for hopelessness also predicted mortality up to 3 years after discharge from ICU $(\mathrm{p}<0.001)$.

Conclusions: The psychological factors ability to cope and hopelessness both strongly affected HRQoL after ICU care, and this effect was stronger than the effects of coexisting disease. Hopelessness also predicted mortality after critical illness. Awareness of the psychological state of patients after a stay in ICU is important to identify which of them are at risk.

Key words: Intensive Care, Psychological factors, Coping ability, SF-36. 


\section{Introduction}

During the past decade there has been an increased focus on the perceived health-related quality of life (HRQoL) for patients who survive critical illness. In addition to the effects of medical treatments, psychosocial factors may also influence HRQoL. These include factors related to the social environment ${ }^{1,2}$ and individual psychological factors, which include psychological resources such as ability to cope, sense of coherence and perceived control, together with psychological risk factors such as depression, exhaustion, and hopelessness ${ }^{3,4}$. We have previously reported on the importance of availability of social integration for HRQoL in patients after critical illness ${ }^{1,2}$, and in this paper we focus on individual psychological factors.

Having a serious illness is, for most people, a stressful experience. According to the cognitive activation theory of stress (CATS), coping is defined as ”positive outcome expectancy based on earlier experiences on the interaction between the exposure and response to this exposure" ${ }^{5}$. This sense of ability to cope captures feelings of confidence and self-reliance together with a feeling that life is to some extent manageable. It describes the ability to respond to external stimuli to prevent, avoid, or control emotional distress, and the extent to which one regards one's chances in life as being under one’s own control in contrast to being in the hands of others ${ }^{6}$. Little or no ability to cope was associated with poorer perceived health among patients with multiple sclerosis ${ }^{7}$ and patients with asthma or chronic obstructive pulmonary disease ${ }^{8}$. In population-based studies little ability to cope was related to poor selfrated health ${ }^{9}$, lower HRQoL scores ${ }^{10}$ and, prospectively, to a higher risk of death from myocardial infarction as well as mortality from all other causes ${ }^{11}$.

If a person cannot cope they lose a sense of expectancy and, if it is prolonged, it turns to a state of helplessness, exhaustion, and hopelessness ${ }^{5,12}$. Hopelessness has been associated with poorer HRQoL in patients with cancer ${ }^{13}$ and HIV ${ }^{14}$. In cardiac patients, 
hopelessness was associated with a more than three-fold risk of clinical events 2 years after their first admission ${ }^{15}$ and in normal populations it has been an independent predictor of myocardial infarction, and deaths both from cardiac disease and other conditions ${ }^{16}$. However, ability to cope and hopelessness have never been examined in relation to HRQoL or mortality in patients after critical care.

The aim of this study was to assess the independent associations between ability to cope and hopelessness with measures of HRQoL and their effects on mortality 3 years after discharge in patients who have been treated in ICU. We hypothesised that inability to cope and severe hopelessness, or both, would be associated with worse perceived HRQoL and with higher mortality after critical care.

\section{Patients and methods}

\section{Design}

This study is part of a larger, prospective, multicentre study in which we earlier explored social integration, HRQoL, and sleep disorders after critical illness ${ }^{17,}{ }^{18}$. The study took place in 3 mixed medical/surgical ICU in one university and 2 general hospitals in south-east Sweden, with a referral area that covers one million people. Patients with primary coronary disease, those recovering from cardiac or neurosurgery, neonates, or patients with burns (who were treated in other specialised units) were excluded. Each ICU admitted 500 - 750 patients annually and nearly all admissions were emergencies. The most common reasons for admission (primary diagnoses) were multiple trauma, sepsis, and respiratory or circulatory disturbances.

\section{Participants}


We included consecutive patients $>18$ years old who were admitted to ICU during the period 1 August, 2000-July 2004, remained in the ICU for more than 24 hours, were alive 6 months after discharge from hospital, and consented to participate in the study. Only the first admission was considered. After we had checked the national Swedish Social Security register to avoid sending inquiries to patients who had died, information and a request to participate were sent by mail, together with a questionnaire and a preaddressed and prepaid envelope 6 12, 24, and 36 months after discharge ${ }^{17}$. Patients who had not responded within 10 days were contacted by telephone and if there was no answer 2 more reminders were sent out (at 3 and 6 weeks). For the purpose of this study data at 6 months were used for analysing association between ability to cope, hopelessness, and HRQoL and for the prospective analysis of effects on mortality.

Ethics, consent and permissions

The patients gave their informed consent prior to participating in the study.

The Ethics Committee at Linköping University approved the design of the original study (Dnr: 00-381).

\section{Measurements:}

\section{Ability to cope}

We used the Mastery Scale questionnaire with 7 items developed by Pearlin ${ }^{19}$ (see appendix for the questionnaire). Typical items were "What happens to me in the future mostly depends on me" and "I can do just about anything I really set my mind to".

The strength of agreement or disagreement for each item was graded on a Likert scale and responses were graded from 1 to 4 . The scores ranged from 7 to 28, and higher scores reflected better ability to cope. 


\section{Hopelessness}

Hopelessness was measured using two items in a scale used by Everson et al ${ }^{16}$ "I feel that it is impossible to reach the goals I would like to strive for" and "The future to me seems hopeless, and I can't believe that it will change to the better”. Responses were graded from 0 to 4 on a Likert scale and summed to create a hopelessness scale ranging from $0-8$, with high scores indicating increasing hopelessness. The scores were also grouped, as originally proposed ${ }^{16}$, into 3 categories: low (0-2), moderate (3-5), and high (6-8). Both scales have been used in many different settings internationally, by others and by members in our group, and their validity and reliability has been confirmed ${ }^{20,21}$.

\section{Health-related quality of life}

The Swedish version of Medical Outcome Short Form (SF-36) ${ }^{22,23}$ was chosen for the evaluation of HRQoL. The instrument is internationally well-known and has been recommended for assessment of HRQoL in critical care ${ }^{24}$. SF-36 has been validated in a representative Swedish sample ${ }^{22}$, and in burned patients ${ }^{25}$. It has 36 questions and generates a health profile of 8 subscales of which 4 relate to physical dimensions (physical functioning; physical role; bodily pain, and general health), and 4 to mental dimensions (vitality; social functioning; emotional role, and mental health) ${ }^{22}$. The scores of all 8 scales were transformed to a scale ranging from 0 (worst) to 100 (best).

\section{Confounding factors}

The questionnaire contained standard questions on age, sex, education, marital status, country of origin, and the scale Availability of Social Integration.

The ICU clinical database was used to extract the reason for admission, Acute Physiology and 
Chronic health Evaluation II (APACHE) II score, time on the ventilator, and duration of stay on the ICU and hospital.

\section{Statistical methods}

Data are presented as mean (SD) and percentages. To assess the significance of differences between the groups, we used Student's $t$ test for continuous data and the chi square test for categorical data. A linear mixed-model was used to get an overall test for significance between the groups with the follow-up time points taken into account. Multiple linear regression analyses were used to evaluate the independent effects of ability to cope and hopelessness on each of the 8 subscales of SF-36. In these models age and sex were entered first, followed by possible confounders (APACHE II scores on admission, duration of stay in ICU and hospital, reason for admission, time on ventilator, marital state, level of education, born in Sweden or not, availability of social integration, and coexisting diseases) in a stepwise manner and standardised beta. To investigate the predictive effects of coping and hopelessness on mortality we used a logistic regression model, and controlled for age and sex and other confounders as given above. In these models age, ability to cope, hopelessness, and availability of social integration were introduced as continuous variables, all others being categorical variables. Probabilities of less than 0.05 were accepted as significant. We used IBM SPSS Statistics for Windows (version 20.0, IBM Corp, Armonk, NY, USA) in the statistical analyses.

\section{Results}

\section{Study population}

A total of 1663 patients met the inclusion criteria, and after two reminders, 980 patients (59\%) answered the questionnaire at six months. See Table 1 for sociodemographic 
characteristics of the study group. Compared with non-responders, the responders were more often male ( $\mathrm{n}=683 ; 52 \%) \quad(\mathrm{p}=0.02)$, had lower APACHE II scores $(\mathrm{p}=0.04)$, but longer mean duration of stay in the ICU $(p<0.0001)$, and longer mean time on a ventilator $(\mathrm{p}<0.0001)$, (for further details see ${ }^{1}$.

Table 1 Sociodemographic characteristics of patients in the study group.

Data are number (\%) except where otherwise stated.

Mean (SD) age (years)

Study group

$(\mathrm{n}=980)$

$18(58)$

Female sex

$567(42)$

Education $^{\mathrm{a}}(\mathrm{n}=597)$

Compulsory school

$380(39)$

High school/ university

$217(22)$

Marital state $^{\mathrm{a}}(\mathrm{n}=966)$

Single

Married/cohabiting

598 (62)

Other

110 (11)

Employment

Employed/leader

371 (38)

Retired

491 (50)

Student

Other

91 (9)

Ability to cope ${ }^{b}$

Hopelessness $^{\mathrm{b}}$

Low (value 0-2)

485 (64.1)

Moderate (value 3-5)

191 (25.2) 
High (value 6-8)

Coexisting diseases

Cancer

Diabetes

Cardiovascular

Gastrointestinal

Miscellaneous
$81(10.7)$

568 (73)

86 (15)

102 (18)

131 (23)

89 (16)

503 (88)

${ }^{\text {a }}$ Not all patients answered all questions

${ }^{\mathrm{b}} 6$ months after ICU

Ability to cope, hopelessness, and coexisting disease

Patients who had been in ICU and had coexisting diseases reported lower mean scores for ability to cope and a higher proportion complained of severe hopelessness compared with patients who were healthy before they were admitted.

Changes in ability to cope and hopelessness between survivors and non-survivors over time Compared with survivors, non-survivors had lower mean scores for ability to cope and higher mean scores for hopelessness at 6 months and also at 12, 24, and 36 months after discharge from hospital. There were significant differences between groups on all occasions, but no significant change within groups over time in either variable (Table 2). 
Table 2 Ability to cope and hopelessness over time for survivors and non-survivors during the study.

\begin{tabular}{llll}
\hline Time (months) & Survivors & Non-survivors & P value
\end{tabular}

\begin{tabular}{|c|c|c|c|}
\hline \multicolumn{4}{|c|}{ Ability to cope } \\
\hline 6 & $\begin{array}{l}21.2(4.0) \\
(n=763)\end{array}$ & $\begin{array}{l}19.2(4.8) \\
(n=108)\end{array}$ & $<0.001$ \\
\hline 12 & $\begin{array}{l}21.3(4.0) \\
(n=628)\end{array}$ & $\begin{array}{l}18.7(4.4) \\
(n=67)\end{array}$ & $<0.001$ \\
\hline 24 & $\begin{array}{l}21.1(4.1) \\
(n=539)\end{array}$ & $\begin{array}{l}19.2(3.6) \\
(n=29)\end{array}$ & 0.016 \\
\hline 36 & $\begin{array}{l}21.1(4.4) \\
(n=472)\end{array}$ & 0 & $\begin{array}{l}\text { Overall difference } \\
\text { between survivors and } \\
\text { non-survivors: } 2.2 \text {, } \\
p<0.001\end{array}$ \\
\hline & & & \\
\hline 6 & $\begin{array}{l}2.4(2.1) \\
(n=813)\end{array}$ & $\begin{array}{l}3.7(2.5) \\
(n=113)\end{array}$ & $<0.001$ \\
\hline 12 & $\begin{array}{l}2.4(2.1) \\
(n=660)\end{array}$ & $\begin{array}{l}4.0(2.4) \\
(n=71)\end{array}$ & $<0.001$ \\
\hline 24 & $\begin{array}{l}2.4(2.2) \\
(n=549)\end{array}$ & $\begin{array}{l}4.0(2.4) \\
(n=32)\end{array}$ & 0.001 \\
\hline 36 & $\begin{array}{l}2.4(2.1) \\
(n=488)\end{array}$ & 0 & $\begin{array}{l}\text { Overall difference } \\
\text { between survivors and } \\
\text { non-survivors: }-1.5 \text {, } \\
p<0.001\end{array}$ \\
\hline
\end{tabular}


Data are mean (SD). P values for the differences between survivors and nonsurvivors were derived using Student's $t$ test. The overall $p$ value for the difference was calculated using the linear mixed model.

\section{HRQoL}

After control for effects of possible confounders in the multiple linear regression analysis, ability to cope and hopelessness were both significantly related to all 8 scales of SF-36, except for coping and bodily pain (Table 3). For the physically-orientated scales the standard betas were in the same group as for coexisting disease, while for social and mental dimensions they were higher.

\section{(Table 3 in about here)}

\section{Mortality}

Between 6 months and 3 years after discharge from the hospital 123 (12. 6\%) patients died. After controlling for possible confounders in regression models, age $(\mathrm{p}<0.001)$, hopelessness $(p<0.00)$, and coexisting disease $(p<0.01)$ gave significant positive associations with mortality $\left(p^{<0.01)}\right.$ (Table 4). The percentage of explained variability was: age $10.4 \%$, hopelessness $6.5 \%$, and coexisting disease $3.6 \%$.

Table 4 Factors that affected death up to three years after ICU discharge.

Survived ( $\mathrm{n}=857$ ) compared with died $(n=123)$

Odds Ratio

Source $P$ value $(95 \% \mathrm{Cl})$ 


\begin{tabular}{|c|c|c|}
\hline Ability to cope & 0.07 & $\begin{array}{c}0.94 \\
(0.87 \text { to } 1.01)\end{array}$ \\
\hline Hopelessness & $<0.04$ & $\begin{array}{c}1.15 \\
\text { (1.01 to } 1.32)\end{array}$ \\
\hline APACHE II score & 0.48 & $\begin{array}{c}1.01 \\
\text { (0.98 to } 1.05)\end{array}$ \\
\hline Duration of stay in ICU & 0.51 & $\begin{array}{c}1.00 \\
\text { (0.99 to } 1.01)\end{array}$ \\
\hline $\begin{array}{l}\text { Duration of stay in } \\
\text { hospital }\end{array}$ & 0.55 & $\begin{array}{c}1.00 \\
(0.99 \text { to } 1.02)\end{array}$ \\
\hline Hours on ventilator & 0.64 & $\begin{array}{c}1.00 \\
\text { (0.99 to } 1.01)\end{array}$ \\
\hline $\begin{array}{l}\text { Marital state (living } \\
\text { alone) }\end{array}$ & 0.96 & $\begin{array}{c}0.99 \\
(0.61 \text { to } 1.60)\end{array}$ \\
\hline Education & & \\
\hline Basic school & 0.91 & $\begin{array}{c}1.03 \\
\text { (0.61 to } 1.75)\end{array}$ \\
\hline High school/university & 0.15 & $\begin{array}{c}1.56 \\
\text { (0.85 to } 2.87)\end{array}$ \\
\hline Born i Sweden & 0.72 & $\begin{array}{c}1.18 \\
\text { (0.48 to } 2.87)\end{array}$ \\
\hline Sex (male) & 0.15 & $\begin{array}{c}1.42 \\
\text { (0.88 to } 2.28)\end{array}$ \\
\hline Age & $<0.001$ & $\begin{array}{c}1.05 \\
\text { (1.03 to } 1.07)\end{array}$ \\
\hline $\begin{array}{l}\text { Availability of social } \\
\text { integration }\end{array}$ & 0.92 & $\begin{array}{c}1.00 \\
(0.95 \text { to } 1.04)\end{array}$ \\
\hline Coexisting disease & 0.03 & $\begin{array}{c}2.17 \\
(1.08 \text { to } 4.31)\end{array}$ \\
\hline \multicolumn{3}{|c|}{ Results from the final multivariable } \\
\hline \multicolumn{3}{|l|}{ logistic regression model } \\
\hline \multicolumn{3}{|c|}{ Values in bold are significant } \\
\hline \multicolumn{3}{|l|}{ Adjusted for age and sex } \\
\hline APACHE=Acute physiolc & ical and c & ronic health \\
\hline
\end{tabular}




\section{Discussion}

New and important findings in this study were the significant associations between ability to cope and hopelessness with HRQoL in patients after critical care, and also the independent effect of hopelessness at 6 months on risk of death 3 years after care in the ICU.

To our knowledge this is the first study to show that both ability to cope and hopelessness were strongly related to the perceived HRQoL in patients after ICU. Our findings confirm what is known about these factors being influential in HRQoL in other conditions, such as hematological cancer, multiple sclerosis, and COPD (Chronic Obstructive Pulmonary

Disease) ${ }^{7,8,11}$. Notably, the magnitude of this effect was large, and was comparable with that of coexisting disease, one of the most important determinants of HRQoL after critical care ${ }^{17}$. For physically-orientated scales such as physical functioning, this effect was as large as the effects of coexisting disease, while for dimensions such as emotional role and mental health the effects were larger than the effects of coexisting disease. Our results therefore give empirical evidence that supports earlier suggestions about the importance of ability to cope and hopelessness for adjustment after critical illness ${ }^{26,27 .}$

Another important finding was that hopelessness was an independent predictor of mortality after the ICU stay, and this effect was significant after controlling for a broad range of factors related to the severity of the present disease including APACHE II score, duration of stay in ICU and hospital, and time spent on ventilator. It was therefore most probably not a consequence of being terminally ill. Indeed, scores of hopelessness in both population-based studies and groups of patients have been shown to be an independent predictor of risk of somatic disease and death ${ }^{16,28,29}$. Possible pathways by which psychological factors and negative emotions increase the risk of disease include effects on the flexibility of the stress response and the balance in autonomic, neuroendocrine, and 
neuroimmunological systems ${ }^{30}$, which lead to immune dysregulation and low-grade inflammation. Several psychological risk factors such as stress and depression have been linked to low grade inflammation ${ }^{31}$. Notably, severe hopelessness using this scale has been shown to be related independently with higher concentrations of the cytokine interleukin- $6{ }^{32}$, with flatter diurnal deviation in salivary cortisol concentrations (34), and with a higher incidence of myocardial infarction (11), and this was also seen after controlling for the effects of depression ${ }^{33}$.

The results illustrate the importance of the psychological state of patients in ICU and of identifying patients with little ability to cope and severe feelings of hopelessness, and helping them to find strategies to adapt after critical illness. Critically ill patients with chaotic and fragmentary memories from their ICU stay may have difficulty in understanding and managing their traumatic experience, and this can lead to a reduction in their ability to cope and a feeling of hopelessness ${ }^{34}$. Evidence suggests that this can be improved by empowerment strategies that involve explaining what is happening to the patients and their families during rehabilitation and the progress of recovery after care in the ICU ${ }^{35}$, but more research is warranted ${ }^{36}$.

\section{Limitations}

For obvious reasons we did not assess ability to cope, hopelessness, or HRQoL among the patients before the period of care in the ICU. However, the important question in this study is the psychological state after ICU and its effects on patients' future health. It will be important in future studies to assess their psychological state before and during the stay in ICU, to allow greater awareness of patients at high risk during the episode of treatment.

Patients in this study were recruited $>10$ years ago and follow up was completed during 2007. The principal differences between the study cohort and an identically selected cohort of 
ICU patients from 2016, was that current patients are on average two years older, their ICU stay is on average a few hours shorter and risk-adjusted mortality is slightly reduced (www.icuregswe.org). The most important change in care practices compared to a decade ago is probably an increased participation in post-ICU care. It is unlikely that these changes are important enough to overturn the major findings of the present study. Indeed, the increased availability of structured post-ICU care may be one way to remedy the reduced physical and mental wellbeing and its association with hopelessness.

Our measure of coexisting disease does have limitations as we have only information about the presence of, and not the severity of, such diseases. However, the measure used was strongly related to both HRQoL (1) and mortality, and does capture important information. We have previously shown that when social integration was available it was associated with better scores on both physical and mental HRQoL to a greater extent than age, sex, and ICUrelated factors ${ }^{1}$. In the present analysis social integration had only a marginal effect on HRQoL, which can be explained by collinearity between it, ability to cope, and hopelessness. Finally, it is important to note that relations to HRQoL were analysed in a cross-sectional design and so we could not consider causation.

The strengths of the study are the large sample, the use of validated instruments, and the prospective design of effects of psychosocial instruments on mortality. The group of patients that we have reported has previously been examined from several different perspectives ${ }^{1,17,18}$. Background characteristics (APACHE II, duration of stay, and reason for admission) and results are comparable with those of other general studies of ICU in northern Europe $^{37,38}$. It may therefore be assumed that the present findings are also valid for other ICU in this part of the world.

\section{Conclusions}


New and relevant findings were that the effects of ability to cope and hopelessness are as important as coexisting diseases for HRQoL in former patients from ICU. Hopelessness was an independent predictor of mortality after the ICU follow-up period. Data strongly suggest the need to identify signs of poor ability to cope and severe hopelessness among ICU patients, to enable psychosocial support to be given during and after the period in ICU.

\section{Acknowledgements}

We are grateful to the participants from Jönköping (Eva) and Norrköping (Carl) who energetically completed this study. 


\section{References}

[1]Orwelius L, Bäckman C, Fredrikson M, et al.: Social integration: an important factor for health-related quality of life after critical illness. Intensive Care Med:DOI 10.1007/s0013400011-02137-00130, 2011

[2] Antonelli M, Bonten M, Chastre J, et al.: Year in review in Intensive Care Medicine 2011. II. Cardiovascular, infections, pneumonia and sepsis, critical care organization and outcome, education, ultrasonography, metabolism and coagulation. Intensive Care Med 38:345-358, 2012

[3] Allart P, Soubeyran P, Cousson-Gelie F: Are psychosocial factors associated with quality of life in patients with haematological cancer? A critical review of the literature. Psychooncology 22:241-249, 2013

[4] Hu J, Meek P: Health-related quality of life in individuals with chronic obstructive pulmonary disease. Heart \& lung : the journal of critical care 34:415-422, 2005

[5] Ursin H, Eriksen HR: The cognitive activation theory of stress.

Psychoneuroendocrinology 29:567-592, 2004

[6] Pearlin LI, Lieberman MA, Menaghan EG, et al.: The stress process. J Health Soc Behav 22:337-356, 1981

[7] Krokavcova M, Nagyova I, Van Dijk JP, et al.: Mastery, functional disability and perceived health status in patients with multiple sclerosis. Eur J Neurol 15:1237-1244, 2008

\{8] Hesselink AE, Penninx BW, Schlösser MA, et al.: The role of coping resources and coping style in quality of life of patients with asthma or COPD. Qual Life Res Mar;13:509518, 2004

[9] Kristenson M, Olsson AG, Kucinskiene Z: Good self-rated health is related to psychosocial resources and a strong cortisol response to acute stress: the LiVicordia study of middle-aged men. Int J Behav Med 12:153-160, 2005

[10] Nilsson E, Kristenson M: Psychological factors related to physical, social, and mental dimensions of the SF-36: a population-based study of middle-aged women and men. Patient Relat Outcome Meas Jul;1:153-162, 2010

[11] Lundgren O, Garvin P, Jonasson L, et al.: Psychological resources are associated with reduced incidence of coronary heart disease. An 8-year follow-up of a community-based Swedish sample. Int J Behav Med Feb;22:77-84, 2015

[12] Kristenson M, Eriksen HR, Sluiter JK, et al.: Psychobiological mechanisms of socioeconomic differences in health. Social science \& medicine 58:1511-1522, 2004 [13] Grassi L, Berardi M, Ruffilli F, et al.: Role of psychosocial variables on chemotherapyinduced nausea and vomiting and health-related quality of life among cancer patients: a European study. Psychother Psychosom 84:339-347, 2015

[14] Siril H, Fawzi MC, Todd J, et al.: Hopefulness Fosters Affective and Cognitive Constructs for Actions to Cope and Enhance Quality of Life among People Living with HIV in Dar Es Salaam, Tanzania. Journal of the International Association of Providers of AIDS Care, 2014

[15] Pedersen SS, Denollet J, Daemen J, et al.: Fatigue, depressive symptoms, and hopelessness as predictors of adverse clinical events following percutaneous coronary intervention with paclitaxel-eluting stents. J Psychosom Res Apr;62:455-461, 2007 [16] Everson S, Goldberg D, Kaplan G, et al.: Hopelessness and Risk of Mortality and Incidence of Myocardial Infarction and Cancer. Psychosomatic Medicine 58:113-121, 1996 
[17] Orwelius L, Nordlund A, Nordlund P, et al.: Pre-existing disease: the most important factor for health related quality of life long-term after critical illness: a prospective, longitudinal, multicentre trial. Crit Care 14:R67:doi:10.1186/cc8967, 2010

[18] Orwelius L, Nordlund A, Nordlund P, et al.: Prevalence of sleep disturbances and longterm reduced health-related quality of life after critical care: a prospective multicenter cohort study. Crit Care 12:Available online http://ccforum.com/content/12/14/R97, 2008

[19] Pearlin LI, Schooler C: The structure of coping. Journal of Health and Social Behavior 19:2-21, 1978

[20] Marteinsdottir I, Ernerudh J, Jonasson L, et al.: Psychological Resources Are Independently Associated with Markers of Inflammation in a Middle-Aged Community Sample. Int J Behav Med, 2016

[21] Garvin P, Jonasson L, Nilsson L, et al.: Plasma Matrix Metalloproteinase-9 Levels Predict First-Time Coronary Heart Disease: An 8-Year Follow-Up of a Community-Based Middle Aged Population. PloS one 10:e0138290, 2015

[22] Sullivan M, Karlsson J, Ware JE, Jr.: The Swedish SF-36 Health Survey--I. Evaluation of data quality, scaling assumptions, reliability and construct validity across general populations in Sweden. Social science \& medicine 41:1349-1358, 1995

[23] Ware JE, Jr., Sherbourne CD: The MOS 36-item short-form health survey (SF-36). I. Conceptual framework and item selection. Med Care 30:473-483, 1992

[24] Angus DC, Carlet J: Surviving intensive care: a report from the 2002 Brussels Roundtable. Intensive Care Med 29:368-377, 2003

[25] Edgar D, Dawson A, Hankey G, et al.: Demonstration of the validity of the SF-36 for measurement of the temporal recovery of quality of life outcomes in burns survivors. Burns 36:1013-1020, 2010

[26] Scheier MF, Carver CS: Optimism, coping and health: Assessment and implications of generalized outcome expectancies. Health Psycho 4:219-247, 1985

[27] Snyder U, Moergeli H, Trentz O, et al.: prediction of Psychiatric Morbidity in severely Injured Accident Victims at One-year Follow-up. Am J Respir Crit Care Med 164:653-656, 2001

[28] Everson SA, Kaplan GA, Goldberg DE, et al.: Hypertension incidence is predicted by high levels of hopelessness in Finnish men. Hypertension 35:561-567, 2000

[29] Garvin P, Nilsson L, Carstensen J, et al.: Plasma levels of matrix metalloproteinase-9 are independently associated with psychosocial factors in a middle-aged normal population.

Psychosom Med 71:292-300, 2009

[30] Kiecolt-Glaser JK, McGuire L, Robles TF, et al.: Psychoneuroimmunology and psychosomatic medicine: back to the future. Psychosom Med 64:15-28, 2002

[31] Reiche EM, Nunes SO, Morimoto HK: Stress, depression, the immune system, and cancer. The Lancet Oncology 5:617-625, 2004

[32] Mitchell AM, Pössel P, Sjögren E, et al.: Hopelessness the "active ingredient"? Associations of hopelessness and depressive symptoms with interleukin-6. Int J Psychiatry Med 46:109-117, 2013

[33] Possel P, Mitchell AM, Sjogren E, et al.: Do depressive symptoms mediate the relationship between hopelessness and diurnal cortisol rhythm? Int J Behav Med 22:251-257, 2015

[34] Corrigan I, Samuelson K, Fridlund B, et al.: The meaning of posttraumatic stressreactions following critical illness or injury and intensive care treatment. Intensive \& critical care nursing : the official journal of the British Association of Critical Care Nurses 23:206215, 2007 
[35] Griffiths RD, Jones C: Seven lessons from 20 years of follow-up of intensive care unit survivors. Curr Opin Crit Care 13:508-513, 2007

[36] Rattray JE, Hull AM: Emotional outcome after intensive care: literature review. J Adv Nurs 64:2-13, 2008

[37] Flaatten H, Kvale R: Survival and quality of life 12 years after ICU. A comparison with the general Norwegian population. Intensive Care Med 27:1005-1011, 2001

[38] Vedio A, Chinn S, Warburton F, et al.: Assessment of survival and quality of life after discharge from a teaching hospital general intensive care unit. Clinical Intensive Care 11:3946, 2000

\section{Web reference}

www.icuregswe.org, accessed April 8, 2017 
Table 3 Relations between HRQoL (SF-36) and different factors. Results from the final multivariable linear regression model (95\% CI for standadized B) (n=980)

\begin{tabular}{|c|c|c|c|c|c|c|c|c|}
\hline & $\mathrm{PF}$ & $\mathrm{RP}$ & BP & GH & VT & SF & $\mathrm{RE}$ & MH \\
\hline & B & B & B & $\mathrm{B}$ & B & B & B & B \\
\hline Source & $(95 \%$ CI) & $(95 \% \mathrm{CI})$ & $(95 \% \mathrm{CI})$ & $(95 \% \mathrm{CI})$ & $(95 \% \mathrm{CI})$ & $(95 \% \mathrm{CI})$ & $(95 \% \mathrm{CI})$ & $(95 \% \mathrm{CI})$ \\
\hline \multirow[t]{2}{*}{ Ability to cope } & 0.17 & 0.15 & 0.07 & 0.23 & 0.28 & 0.30 & 0.21 & 0.38 \\
\hline & (0.10 to 0.28 ) & (0.07 to 0.23 ) & (-0.01 to 0.16$)$ & (0.14 to 0.28 ) & (0.18 to 0.32 ) & (0.23 to 0.39 ) & (0.15 to 0.33 ) & (0.31 to 0.45 ) \\
\hline \multirow[t]{2}{*}{ Hopelessness } & -0.16 & -0.18 & -0.30 & -0.28 & -0.30 & -0.27 & -0.31 & -0.30 \\
\hline & $(-0.30$ to -0.11$)$ & $(-0.30$ to -0.11$)$ & $(-0.39$ to -0.24$)$ & $(-0.36$ to -0.21$)$ & $(-0.38$ to -0.23$)$ & $(-0.41$ to -0.23$)$ & $(-0.50$ to -0.29$)$ & $(-0.42$ to -0.26$)$ \\
\hline \multirow[t]{2}{*}{ Age } & -2.27 & -0.18 & -0.05 & -0.05 & 0.01 & 0.02 & -0.03 & 0.14 \\
\hline & $(-0.38$ to -0.24$)$ & $(-0.25$ to -0.12$)$ & (-0.12 to 0.02$)$ & (-0.11 to 0.01$)$ & $(-0.05$ to 0.07$)$ & $(-0.04$ to 0.10$)$ & (-0.11 to 0.04$)$ & (0.09 to 0.20 ) \\
\hline \multirow[t]{2}{*}{ Sex (male) } & -0.10 & 0.02 & -0.01 & -0.02 & -0.04 & 0.01 & -0.06 & -0.02 \\
\hline & $(-0.20$ to -0.05$)$ & $(-0.04$ to 0.10$)$ & $(-0.09$ to 0.06$)$ & $(-0.08$ to 0.03$)$ & $(-0.11$ to 0.02$)$ & (.0.07 to 0.07$)$ & $(-0.16$ to -0.01$)$ & (-0.09 to 0.04$)$ \\
\hline \multirow[t]{2}{*}{ APACHE II score } & 0.02 & 0.04 & 0.08 & 0.03 & 0.08 & 0.07 & 0.02 & 0.02 \\
\hline & (-0.05 to 0.12$)$ & $(-0.03$ to 0.13$)$ & (0.01 to 0.16 ) & $(-0.03$ to 0.09$)$ & (0.02 to 0.15 ) & (0.01 to 0.16 ) & $(-0.06$ to 0.11$)$ & (-0.04 to 0.09$)$ \\
\hline \multirow[t]{2}{*}{ Duration of stay in ICU } & -0.03 & -0.03 & -0.05 & -0.02 & -0.02 & -0.04 & 0.02 & 0.01 \\
\hline & $(-0.12$ to 0.04$)$ & $(-0.17$ to 0.09$)$ & $(-0.13$ to 0.02$)$ & $(-0.08$ to 0.04$)$ & $(-0.09$ to 0.04$)$ & $(-0.12$ to 0.03$)$ & $(-0.05$ to 0.11$)$ & (-0.11 to 0.11$)$ \\
\hline \multirow[t]{2}{*}{ Duration of stay in hospital } & -0.12 & -0.04 & 0.01 & -0.01 & -0.02 & -0.02 & -0.03 & 0.01 \\
\hline & $(-0.24$ to -0.08$)$ & $(-0.13$ to 0.02$)$ & $(-0.06$ to 0.09$)$ & $(-0.07$ to 0.06$)$ & $(-0.08$ to 0.05$)$ & $(-0.10$ to 0.059 & (.0.12 to 0.04$)$ & (-0.05 to 0.08$)$ \\
\hline Reason for admission & 0.10 & 0.16 & 0.20 & 0.05 & 0.08 & 0.05 & 0.04 & 0.03 \\
\hline
\end{tabular}




\begin{tabular}{|c|c|c|c|c|c|c|c|c|}
\hline & (0.06 to 0.21$)$ & (0.12 to 0.26$)$ & (0.16 to 0.29$)$ & $(-0.01$ to 0.11$)$ & (0.02 to 0.14 ) & $(-0.01$ to 0.13$)$ & $(-0.03$ to 0.12$)$ & $(-0.03$ to 0.09 ( \\
\hline \multirow[t]{2}{*}{ Hours on ventilator } & 0.026 & -0.08 & -0.02 & 0.04 & 0.03 & 0.04 & -0.06 & 0.06 \\
\hline & (-1.10 to 0.17$)$ & $(-0.16$ to -0.03$)$ & $(-0.15$ to 0.10$)$ & (-0.06 to 0.14$)$ & (-0.06 to 0.13$)$ & $(-0.07$ to 0.17$)$ & (.0.21 to 0.06$)$ & (0.01 to 0.14 ) \\
\hline \multirow[t]{2}{*}{ Marital state (living alone) } & -0.04 & -0.01 & -0.01 & 0.03 & 0.00 & -0.08 & -0.07 & -0.08 \\
\hline & $(-0.13$ to 0.02$)$ & $(-0.08$ to 0.07$)$ & $(-0.09$ to 0.06$)$ & (-0.03 to 0.09$)$ & $(-0.06$ to 0.06$)$ & $(-0.17$ to -0.03$)$ & $(-0.17$ to -0.01$)$ & $(-0.15$ to -0.03$)$ \\
\hline \multicolumn{9}{|l|}{ Education } \\
\hline \multirow[t]{2}{*}{ Basic school } & 0.007 & 0.06 & 0.05 & 0.03 & 0.13 & 0.12 & 0.01 & 0,07 \\
\hline & $(-0.08$ to 0.10$)$ & (0.01 to 0.15 ) & $(-0.02$ to 0.13$)$ & $(-0.02$ to 0.09$)$ & (0.08 to 0.20$)$ & (0.08 to 0.22$)$ & $(-0.08$ to 0.10$)$ & (0.02 to 0.14$)$ \\
\hline \multirow[t]{2}{*}{ High school/university } & -0.02 & 0.00 & -0.03 & 0.02 & 0.01 & 0.04 & 0.04 & 0.04 \\
\hline & $(-0.10$ to 0.06$)$ & (-0.08 to 0.08$)$ & (-0.11 to 0.05$)$ & $(-0.04$ to 0.08$)$ & $(-0.06$ to 0.07$)$ & $(-0.03$ to 0.12$)$ & $(-0.03$ to 0.13$)$ & $(-0.02$ to 0.11$) \mathrm{s}$ \\
\hline \multirow[t]{2}{*}{ Born in Sweden } & -0.003 & -0.02 & -0.04 & 0.01 & 0.01 & 0.01 & -0.03 & -0.03 \\
\hline & $(-0.08$ to 0.08$)$ & $(-0.10$ to 0.05$)$ & $(-0.12$ to 0.03$)$ & $(-0.06$ to 0.06$)$ & $(-0.05$ to 0.07$)$ & $(-0.06$ to 0.08$)$ & $(-0.12$ to 0.05$)$ & $(-0.10$ to 0.03$)$ \\
\hline \multirow[t]{2}{*}{ Availability of social integration } & 0.04 & 0.03 & 0.08 & 0.06 & 0.05 & 0.05 & 0.04 & 0.07 \\
\hline & $(-0.03$ to 0.13$)$ & $(-0.05$ to 0.11$)$ & (0.02 to 0.16$)$ & (0.01 to 0.13 ) & $(-0.01$ to 0.12$)$ & $(-0.02$ to 0.13$)$ & (-0.04 to 0.13$)$ & (0.02 to 0.15$)$ \\
\hline \multirow[t]{2}{*}{ Coexisting disease } & 0.17 & 0.20 & 0.20 & 0.28 & 0.17 & 0.17 & 0.10 & 0.08 \\
\hline & (0.16 to 0.33 ) & (0.17 to 0.33 ) & (0.17 to 0.33 ) & $(0.27$ to 0.40$)$ & (0.14 to 0.23 ) & (0.15 to 0.31$)$ & (0.05 to 0.22$)$ & (0.03 to 0.17 ) \\
\hline R2 & 0.28 & 0.23 & 0.19 & 0.40 & 0.34 & 0.35 & 0.28 & 0.47 \\
\hline
\end{tabular}

R2 are adjusted value in the final model

Values in bold are significant $(\mathrm{p}<0.05)$

PF; Physical Functioning, RP; Role-Physical, BP; Bodily Pain, GH; General Health, VT; Vitality, SF; Social Functioning, RE; Role Emotional, MH; Mental Health SF-36; Short form 36, APACHE; Acute physiological and chronic health evaluation, 
Table 3 Relations between HRQoL (SF-36) and different factors. Results from the final multivariable linear regression model (95\% CI for standadized B) (n=980)

\begin{tabular}{|c|c|c|c|c|c|c|c|c|}
\hline Source & $\begin{array}{c}\text { PF } \\
\text { B } \\
(95 \% \mathrm{CI}) \\
\end{array}$ & $\begin{array}{c}\mathrm{RP} \\
\mathrm{B} \\
(95 \% \mathrm{CI}) \\
\end{array}$ & $\begin{array}{c}\text { BP } \\
\text { B } \\
(95 \% \mathrm{CI}) \\
\end{array}$ & $\begin{array}{c}\mathrm{GH} \\
\mathrm{B} \\
(95 \% \mathrm{CI}) \\
\end{array}$ & $\begin{array}{c}\mathrm{VT} \\
\mathrm{B} \\
(95 \% \mathrm{CI}) \\
\end{array}$ & $\begin{array}{c}\text { SF } \\
\text { B } \\
(95 \% \mathrm{CI}) \\
\end{array}$ & $\begin{array}{c}\text { RE } \\
\text { B } \\
(95 \% \mathrm{CI}) \\
\end{array}$ & $\begin{array}{c}\mathrm{MH} \\
\mathrm{B} \\
(95 \% \mathrm{CI}) \\
\end{array}$ \\
\hline Ability to cope & $\begin{array}{c}\mathbf{0 . 1 7} \\
(0.10 \text { to } 0.28)\end{array}$ & $\begin{array}{c}\mathbf{0 . 1 5} \\
\text { (0.07 to } 0.23)\end{array}$ & $\begin{array}{c}0.07 \\
(-0.01 \text { to } 0.16)\end{array}$ & $\begin{array}{c}\mathbf{0 . 2 3} \\
\text { (0.14 to } 0.28)\end{array}$ & $\begin{array}{c}\mathbf{0 . 2 8} \\
\text { (0.18 to } 0.32)\end{array}$ & $\begin{array}{c}\mathbf{0 . 3 0} \\
(0.23 \text { to } 0.39)\end{array}$ & $\begin{array}{c}\mathbf{0 . 2 1} \\
\text { (0.15 to } 0.33)\end{array}$ & $\begin{array}{c}\mathbf{0 . 3 8} \\
\text { (0.31 to } 0.45)\end{array}$ \\
\hline Hopelessness & $\begin{array}{c}-\mathbf{0 . 1 6} \\
(-0.30 \text { to }-0.11)\end{array}$ & $\begin{array}{c}-\mathbf{0 . 1 8} \\
(-0.30 \text { to }-0.11)\end{array}$ & $\begin{array}{c}-\mathbf{0 . 3 0} \\
(-0.39 \text { to }-0.24)\end{array}$ & $\begin{array}{c}-\mathbf{0 . 2 8} \\
(-0.36 \text { to }-0.21)\end{array}$ & $\begin{array}{c}-\mathbf{0 . 3 0} \\
(-0.38 \text { to }-0.23)\end{array}$ & $\begin{array}{c}-\mathbf{0 . 2 7} \\
(-0.41 \text { to }-0.23)\end{array}$ & $\begin{array}{c}-\mathbf{0 . 3 1} \\
(-0.50 \text { to }-0.29)\end{array}$ & $\begin{array}{c}-\mathbf{0 . 3 0} \\
(-0.42 \text { to }-0.26)\end{array}$ \\
\hline Age & $\begin{array}{c}-\mathbf{2 . 2 7} \\
(-0.38 \text { to }-0.24)\end{array}$ & $\begin{array}{c}-\mathbf{0 . 1 8} \\
(-0.25 \text { to }-0.12)\end{array}$ & $\begin{array}{c}-0.05 \\
(-0.12 \text { to } 0.02)\end{array}$ & $\begin{array}{c}-0.05 \\
(-0.11 \text { to } 0.01)\end{array}$ & $\begin{array}{c}0.01 \\
(-0.05 \text { to } 0.07)\end{array}$ & $\begin{array}{c}0.02 \\
(-0.04 \text { to } 0.10)\end{array}$ & $\begin{array}{c}-0.03 \\
(-0.11 \text { to } 0.04)\end{array}$ & $\begin{array}{c}\mathbf{0 . 1 4} \\
\text { (0.09 to } 0.20)\end{array}$ \\
\hline Sex (male) & $\begin{array}{c}-\mathbf{0 . 1 0} \\
(-0.20 \text { to }-0.05)\end{array}$ & $\begin{array}{c}0.02 \\
(-0.04 \text { to } 0.10)\end{array}$ & $\begin{array}{c}-0.01 \\
(-0.09 \text { to } 0.06)\end{array}$ & $\begin{array}{c}-0.02 \\
(-0.08 \text { to } 0.03)\end{array}$ & $\begin{array}{c}-0.04 \\
(-0.11 \text { to } 0.02)\end{array}$ & $\begin{array}{c}0.01 \\
\text { (.0.07 to } 0.07)\end{array}$ & $\begin{array}{c}-\mathbf{0 . 0 6} \\
(-0.16 \text { to }-0.01)\end{array}$ & $\begin{array}{c}-0.02 \\
(-0.09 \text { to } 0.04)\end{array}$ \\
\hline APACHE II score & $\begin{array}{c}0.02 \\
(-0.05 \text { to } 0.12)\end{array}$ & $\begin{array}{c}0.04 \\
(-0.03 \text { to } 0.13)\end{array}$ & $\begin{array}{c}\mathbf{0 . 0 8} \\
\text { (0.01 to } 0.16)\end{array}$ & $\begin{array}{c}0.03 \\
(-0.03 \text { to } 0.09)\end{array}$ & $\begin{array}{c}\mathbf{0 . 0 8} \\
\text { (0.02 to } 0.15)\end{array}$ & $\begin{array}{c}\mathbf{0 . 0 7} \\
\text { (0.01 to } 0.16)\end{array}$ & $\begin{array}{c}0.02 \\
(-0.06 \text { to } 0.11)\end{array}$ & $\begin{array}{c}0.02 \\
(-0.04 \text { to } 0.09)\end{array}$ \\
\hline Duration of stay in ICU & $\begin{array}{c}-0.03 \\
(-0.12 \text { to } 0.04)\end{array}$ & $\begin{array}{c}-0.03 \\
(-0.17 \text { to } 0.09)\end{array}$ & $\begin{array}{c}-0.05 \\
(-0.13 \text { to } 0.02)\end{array}$ & $\begin{array}{c}-0.02 \\
(-0.08 \text { to } 0.04)\end{array}$ & $\begin{array}{c}-0.02 \\
(-0.09 \text { to } 0.04)\end{array}$ & $\begin{array}{c}-0.04 \\
(-0.12 \text { to } 0.03)\end{array}$ & $\begin{array}{c}0.02 \\
(-0.05 \text { to } 0.11)\end{array}$ & $\begin{array}{c}0.01 \\
(-0.11 \text { to } 0.11)\end{array}$ \\
\hline Duration of stay in hospital & $\begin{array}{c}-\mathbf{0 . 1 2} \\
(-0.24 \text { to }-0.08)\end{array}$ & $\begin{array}{c}-0.04 \\
(-0.13 \text { to } 0.02)\end{array}$ & $\begin{array}{c}0.01 \\
(-0.06 \text { to } 0.09)\end{array}$ & $\begin{array}{c}-0.01 \\
(-0.07 \text { to } 0.06)\end{array}$ & $\begin{array}{c}-0.02 \\
(-0.08 \text { to } 0.05)\end{array}$ & $\begin{array}{c}-0.02 \\
(-0.10 \text { to } 0.059\end{array}$ & $\begin{array}{c}-0.03 \\
(.0 .12 \text { to } 0.04)\end{array}$ & $\begin{array}{c}0.01 \\
(-0.05 \text { to } 0.08)\end{array}$ \\
\hline Reason for admission & $\begin{array}{c}\mathbf{0 . 1 0} \\
(0.06 \text { to } 0.21)\end{array}$ & $\begin{array}{c}\mathbf{0 . 1 6} \\
\text { (0.12 to } 0.26)\end{array}$ & $\begin{array}{c}\mathbf{0 . 2 0} \\
\text { (0.16 to } 0.29)\end{array}$ & $\begin{array}{c}0.05 \\
(-0.01 \text { to } 0.11)\end{array}$ & $\begin{array}{c}\mathbf{0 . 0 8} \\
\text { (0.02 to } 0.14)\end{array}$ & $\begin{array}{c}0.05 \\
(-0.01 \text { to } 0.13)\end{array}$ & $\begin{array}{c}0.04 \\
(-0.03 \text { to } 0.12)\end{array}$ & $\begin{array}{c}0.03 \\
\text { (-0.03 to } 0.09 \text { ( }\end{array}$ \\
\hline Hours on ventilator & $\begin{array}{c}0.026 \\
\text { (-1.10 to } 0.17)\end{array}$ & $\begin{array}{c}-\mathbf{0 . 0 8} \\
(-0.16 \text { to }-0.03)\end{array}$ & $\begin{array}{c}-0.02 \\
(-0.15 \text { to } 0.10)\end{array}$ & $\begin{array}{c}0.04 \\
(-0.06 \text { to } 0.14)\end{array}$ & $\begin{array}{c}0.03 \\
(-0.06 \text { to } 0.13)\end{array}$ & $\begin{array}{c}0.04 \\
(-0.07 \text { to } 0.17)\end{array}$ & $\begin{array}{c}-0.06 \\
(.0 .21 \text { to } 0.06)\end{array}$ & $\begin{array}{c}\mathbf{0 . 0 6} \\
\text { (0.01 to } 0.14)\end{array}$ \\
\hline Marital state (living alone) & $\begin{array}{c}-0.04 \\
(-0.13 \text { to } 0.02)\end{array}$ & $\begin{array}{c}-0.01 \\
(-0.08 \text { to } 0.07)\end{array}$ & $\begin{array}{c}-0.01 \\
(-0.09 \text { to } 0.06)\end{array}$ & $\begin{array}{c}0.03 \\
(-0.03 \text { to } 0.09)\end{array}$ & $\begin{array}{c}0.00 \\
(-0.06 \text { to } 0.06)\end{array}$ & $\begin{array}{c}-\mathbf{0 . 0 8} \\
(-0.17 \text { to }-0.03)\end{array}$ & $\begin{array}{c}\mathbf{- 0 . 0 7} \\
(-0.17 \text { to }-0.01)\end{array}$ & $\begin{array}{c}-\mathbf{0 . 0 8} \\
(-0.15 \text { to }-0.03)\end{array}$ \\
\hline \multicolumn{9}{|l|}{ Education } \\
\hline Basic school & $\begin{array}{c}0.007 \\
(-0.08 \text { to } 0.10)\end{array}$ & $\begin{array}{c}0.06 \\
\text { (0.01 to } 0.15)\end{array}$ & $\begin{array}{c}0.05 \\
(-0.02 \text { to } 0.13)\end{array}$ & $\begin{array}{c}0.03 \\
(-0.02 \text { to } 0.09)\end{array}$ & $\begin{array}{c}\mathbf{0 . 1 3} \\
\text { (0.08 to } 0.20)\end{array}$ & $\begin{array}{c}\mathbf{0 . 1 2} \\
\text { (0.08 to } 0.22)\end{array}$ & $\begin{array}{c}0.01 \\
(-0.08 \text { to } 0.10)\end{array}$ & $\begin{array}{c}\mathbf{0 , 0 7} \\
\text { (0.02 to } 0.14)\end{array}$ \\
\hline High school/university & $\begin{array}{c}-0.02 \\
(-0.10 \text { to } 0.06)\end{array}$ & $\begin{array}{c}0.00 \\
(-0.08 \text { to } 0.08)\end{array}$ & $\begin{array}{c}-0.03 \\
(-0.11 \text { to } 0.05)\end{array}$ & $\begin{array}{c}0.02 \\
(-0.04 \text { to } 0.08)\end{array}$ & $\begin{array}{c}0.01 \\
(-0.06 \text { to } 0.07)\end{array}$ & $\begin{array}{c}0.04 \\
(-0.03 \text { to } 0.12)\end{array}$ & $\begin{array}{c}0.04 \\
(-0.03 \text { to } 0.13)\end{array}$ & $\begin{array}{c}0.04 \\
(-0.02 \text { to } 0.11) \mathrm{s}\end{array}$ \\
\hline Born in Sweden & $\begin{array}{c}-0.003 \\
(-0.08 \text { to } 0.08)\end{array}$ & $\begin{array}{c}-0.02 \\
(-0.10 \text { to } 0.05)\end{array}$ & $\begin{array}{c}-0.04 \\
(-0.12 \text { to } 0.03)\end{array}$ & $\begin{array}{c}0.01 \\
(-0.06 \text { to } 0.06)\end{array}$ & $\begin{array}{c}0.01 \\
(-0.05 \text { to } 0.07)\end{array}$ & $\begin{array}{c}0.01 \\
(-0.06 \text { to } 0.08)\end{array}$ & $\begin{array}{c}-0.03 \\
(-0.12 \text { to } 0.05)\end{array}$ & $\begin{array}{c}-0.03 \\
(-0.10 \text { to } 0.03)\end{array}$ \\
\hline Availability of social integration & 0.04 & 0.03 & 0.08 & 0.06 & 0.05 & 0.05 & 0.04 & 0.07 \\
\hline
\end{tabular}




\begin{tabular}{|c|c|c|c|c|c|c|c|c|}
\hline & ( -0.03 to 0.13$)$ & (-0.05 to 0.11$)$ & (0.02 to 0.16 ) & (0.01 to 0.13 ) & $(-0.01$ to 0.12$)$ & (-0.02 to 0.13$)$ & (-0.04 to 0.13$)$ & (0.02 to 0.15 ) \\
\hline \multirow[t]{2}{*}{ Coexisting disease } & 0.17 & 0.20 & 0.20 & 0.28 & 0.17 & 0.17 & 0.10 & 0.08 \\
\hline & (0.16 to 0.33 ) & (0.17 to 0.33 ) & (0.17 to 0.33 ) & (0.27 to 0.40 ) & (0.14 to 0.23 ) & (0.15 to 0.31 ) & (0.05 to 0.22 ) & (0.03 to 0.17 ) \\
\hline R2 & 0.28 & 0.23 & 0.19 & 0.40 & 0.34 & 0.35 & 0.28 & 0.47 \\
\hline
\end{tabular}

$\mathrm{R} 2$ are adjusted value in the final model

Values in bold are significant $(\mathrm{p}<0.05)$

PF; Physical Functioning, RP; Role-Physical, BP; Bodily Pain, GH; General Health, VT; Vitality, SF; Social Functioning, RE; Role Emotional, MH; Mental Health

SF-36; Short form 36, APACHE; Acute physiological and chronic health evaluation, 


\section{Appendix 1}

\section{Pearlin Mastery Scale Items}

1. There is really no way I can solve some of the problems I have.

2. Sometimes I feel that I'm being pushed around in life.

3. I have little control over the things that happen to me.

4. I can do just about anything I really set my mind to.

5. I often feel helpless in dealing with the problems of life.

6. What happens to me in the future mostly depends on me.

7. There is little I can do to change many of the important things in my life.

The Pearlin Mastery Scale (PM) measures an individual's level of mastery, which is a psychological resource that has been defined as "the extent to which one regards one's life-chances as being under one's own control in contrast to being fatalistically ruled”. The 7-item scale comprises five negatively worded items and two positively worded items, presented with the following response options: (1) Strongly Disagree (2) Disagree (3) Agree (4) Strongly Agree. The negatively worded items require reverse coding prior to scoring, resulting in a score range of 7 to 28 , with higher scores indicating greater levels of mastery.

Mastery has been shown to provide a protective buffer for individuals' mental and physical health and well-being, when facing persistent life stresses, such as economic and occupational hardships (1).

1. Pearlin LI, Schooler C. The structure of coping. Journal of Health and Social Behavior 1978;19(March):2-21. 